\title{
Modifikasi Model Pembelajaran Gerlach dan Ely Melalui Integrasi Nilai-Nilai Keislaman Sebagai Upaya Meningkatkan Kemampuan Representasi Matematis
}

\author{
Irda Yusnita1 ${ }^{1}$, R. Masykur ${ }^{2}$, Suherman ${ }^{3}$ \\ 1,2,3|AIN Raden Intan: irdayusnita7@gmail.com
}

Submitted : 16-02-2016, Revised : 25-04-2016, Accepted : 16-06-2016

\begin{abstract}
This study aims to determine whether the modification of learning models Gerlach and Ely through the integration of Islamic values can improve the ability of mathematical representation of learners. This research uses Pre-Experimental Design method with onegroup pretest-posttest type. The prerequisite analysis test was performed by Liliefors test for normality and F test for homogeneity, then the datawere analyzed by using N-Gain test and correlated t-test. The results of the analysis show that the mathematical representation of learner sincreases after using modified Gerlach and Ely lerning models that are integrated with Islamic values rather than the mathematical representation of learners before using modified Gerlach and Ely learning models through the integration of Islamic Values
\end{abstract}

Keywords : Gerlach and Ely; Integration; Islamization; Mathematical; Representation.

\begin{abstract}
Abstrak
Penelitian ini bertujuan untuk mengetahui apakah modifikasi model pembelajaran Gerlach dan Ely melalui integrasi nilai-nilai kelslaman dapat meningkatkan kemampuan representasi matematis peserta didik. Penelitian ini menggunakan metode Pre-Eksperimental Design dengan jenis one-group pretest-posttest. Pengujian prasyarat analisis dilakukan dengan uji Liliefors untuk normalitas dan uji $F$ untuk homogenitas, selanjutnya data dianalisis dengan menggunakan uji $\mathrm{N}$-Gain dan Uji t-test berkorelasi. Hasil analisis menunjukkan bahwa kemampuan representasi matematis peserta didik meningkat setelah menggunakan modifikasi model pembelajaran Gerlach dan Ely yang diintegrasikan dengan nilai-nilai kelslaman dibandingkan kemampuan representasi matematis peserta didik sebelum menggunakan modifikasi model pembelajaran Gerlach dan Ely melalui integrasi nilai-nilai kelslaman.
\end{abstract}

Kata Kunci: Gerlach dan Ely; Integrasi; Kelslaman; Matematis; Representasi.

\section{PENDAHULUAN}

Pendidikan merupakan usaha sadar dan terencana untuk mewujudkan suasana belajar dan proses pembelajaran agar peserta didik secara aktif mengembangkan potensi dirinya untuk memiliki kekuatan spiritual keagamaan, kepribadian, kecerdasan, serta keterampilan yang diperlukan dirinya dan masyarakat. Dalam UU No. 20 Tahun 2003 juga dijelaskanbahwa pendidikan nasional bertujuan untuk mengembangkan potensi peserta didik sehingga menjadi manusia yang beriman dan bertakwa kepada Tuhan Yang Maha Esa, berakhlak mulia, sehat jasmani dan rohani, cerdas, kreatif, mandiri dan bertanggung 
jawab.Untuk mewujudkan hal tersebut lembaga pendidikan mempunyai peranan yang sangat penting.

Lembaga pendidikan berperan memberikan pemahaman dan benteng pertahanan kepada anak agar terhindar dari hal-hal negatif yang dapat merusak kepribadian dan karakter siswa (Sudijono, 2013). Sebagai antisipasi dampak negatif, lembaga pendidikan selain memberikan bekal ilmu pengetahuan, teknologi dan seni (IPTEKS), serta keterampilan berfikir kreatif, juga harus membentuk manusia Indonesia yang berkepribadian, bermoral, beriman dan bertakwa kepada Tuhan Yang Maha Esa dengan memberikan pendidikan karakter kepada anak (Armiah, 2014). Berbagai macam pelajaran diperkenalkan oleh lembaga pendidikan, salah satunya adalah pelajaran matematika.

Matematika merupakan sebuah ilmu pasti yang menjadi dasar dari ilmu lain, sehingga matematika itu saling berkaitan dengan ilmu lainnya, dan matematika merupakan salah satu mata pelajaran yang menduduki peranan penting dalam dunia pendidikan, namun kenyataannya hasil belajar matematika peserta didik masih sangat rendah. Salah satu faktor yang menyebabkan rendahnya hasil belajar peserta didik adalah karena peserta didik mengalami kesulitan dan belum mampu daalam mengubah pemecahan masalah matematika (Suherman, 2015) apabila diberikan soal-soal yang penyelesaiannya membutuhkan alat bantu yang berupa kata-kata, tulisan, gambar, tabel, grafik, benda konkrit, simbol matematika dan lain-lain untuk menemukan solusi dari masalah tersebut. Oleh karena itu, setiap peserta didik memeiliki kemampuan berbeda-beda dalam menyimpulkan konsep (Widyastuti, 2015). Hal ini diduga bahwa kemampuan representasi matematis peserta didik masih rendah (Gagatsis, 2004).

Kemampuan representasi matematis merupakan bentuk interpretasi pemikiran peserta didik terhadap suatu masalah, yang digunakan sebagai alat bantu untuk menemukan solusi dari masalah tersebut.Pentingnya kemampuan representasi matematis dapat dilihat dari standarrepresentasi yang ditetapkan oleh NCTM (National Council of Teachers of Mathematics). NCTM (2000) menetapkan bahwa programpembelajaran dari pra-taman kanak-kanak sampai kelas 12 harus memungkinkan siswa untuk: (1) menciptakan dan menggunakan representasi untuk mengorganisir, mencatat,dan mengkomunikasikan ide-ide matematis; (2) memilih, menerapkan, danmenerjemahkan representasi matematis untuk memecahkan masalah; dan (3) menggunakan representasi untuk memodelkan dan menginterpretasikan fenomena fisik, sosial, dan fenomena matematis. Dengan demikian, kemampuan representasi matematis diperlukan peserta didik untuk menemukan dan membuat suatu alat atau cara berpikirdalam mengkomunikasikan gagasan matematis dari yang sifatnya abstrak menujukonkret, sehingga lebih mudah untuk dipahami. Tetapi pada kenyataannya kemampuan representasi matematis masih kurang, sehingga masih banyak peserta didik yang kesulitan dalam belajar matematika.

Selain rendahnya kemampuan representasi matematis, minimnya pengetahuan guru terhadap berbagai model pembelajaran juga sangat berpengaruh dalam proses pembelajaran dan mengakibatkan kurang tepatnya model pembelajaran yang digunakan (Isjoni, 2014). Pada pelaksanaan pembelajaran, peserta didik cenderung merasa bosan karena terjadi komunikasi satu arah yang memberikan sedikit kesempatan kepada peserta didik untuk berfikir matematis dan berdiskusi dengan peserta didik lain, sehingga hanya sedikit bentuk representasi matematis yang diketahui dan dikuasai peserta didik. Ini mengakibatkan apabila peserta didik diberikan masalah matematis yang berbeda dengan 
contoh soal atau latihan, peserta didik tidak dapat merepresentasikan masalah matematis tersebut kedalam ekspresi matematis atau gambar sehingga peserta didik tidak bisa menyelesaikan soal tersebut (Effendi, 2014).

Sejalan dengan permasalahan di atas, diperlukan suatu alternatif model pembelajaran yang membuat peserta didik menjadi aktif (Rusman, 2013) dan membuat suasana pembelajaran yang menyenangkan, sehingga peserta didik tidak merasa bosan dalam proses kegiatan belajar mengajar (KBM), serta model pembelajaran yang cocok untuk meningkatkan kemampuan representasi matematis peserta didik.Kemampuan representasi peserta didik dapat dibangun dengan keterlibatan peserta didik secara langsung dalam proses membaca, berpikir, berdialog (Sugiyono, 2012), berbicara, membagi ide (sharing) serta mengembangkan tulisan dengan lancar. Dalam setiap tahapan proses pembelajaran diperlukan suatu model pembelajaran yang mampu mendorong peserta didik untuk mengembangkan proses berpikir dalam upaya meningkatkan ide-ide kreatif peserta didik. Hal ini tentunya tidak terlepas dari peran guru yang menjadi monitoring dan menilai partisipasi peserta didik, sehingga guru harus dapat menggunakan model pembelajaran yang tepat supaya berjalan sesuai skenario yang diharapkan.Salah satu alternatifnya adalah model pembelajaran Gerlach dan Ely.

Model pembelajaran Gerlach dan Ely suatu cara yang sistematis dalam mengidentifikasi, mengembangkan, dan mengevaluasi seperangkat materi danstrategi yang diarahkan untuk mencapai tujuan pendidikan tertentu (Purwanto, 2007). Model pembelajaran Gerlach dan Ely bermanfaat sebagai pedoman atau suatu petaperjalanan dalam membuat suatu rencana proses belajar mengajar yang baik sehingga dapat meningkatkan cara berpikir peserta didik. Dengan demikian maka dapat berpengaruh dalam meningkatkan kemampuan representasi matematis peserta didik.Selain penggunaan model pembelajaran yang tepat, peneliti juga melakukan modifikasi model pembelajaran melalui integrasi nilai-nilai kelslaman karena yang akan menjadi sampel pada penelitian ini adalah sekolah menengah yang berciri khaskan Islam (MTs).

Penelitian yang relevan dengan penelitian ini yaitu sebagai berikut:

a. Penelitin oleh Dwi Endah Pratiwi, pada tahun 2013 dengan judul: "Penerapan Pendekatan Model Eliciting Activities (MEAs) untuk Meningkatkan Kemampuan Representasi Matematis Siswa SMP".

Hasil penelitiannya menyatakan bahwa kualitas peningkatan kemampuan representasi matematis siswa yang memperoleh pembelajaran MEAs berada pada kriteria sedangkan siswa yang memperoleh pembelajaran mekanistik berada pada kriteria rendah. Respon siswa positif terhadap pembelajaran MEAs.

Perbedaan penelitian yang dilakukan oleh Dwi Endah Pratiwi dengan penelitian ini adalah:

a). Model pembelajaran yang digunakan oleh Dwi Endah Pratiwi adalah dengan pendekatan model Eliciting Activities (MEAs), sedangkan pada penelitian ini menggunakan model pembelajaran Gerlach dan Ely.

b). Tempat penelitian Dwi Endah Pratiwi di SMP kelas VIII, sedangkan pada penelitian ini dilakukan di MTs kelas VII.

Persamaan penelitian Dwi Endah Pratiwi dengan penelitian ini adalah sama-sama mengukur meningkatkan kemampuan representasi matematis. 
b. Penelitian oleh Kanisius Mandur, I Wayan Sandra, I Nengah Suparta pada tahun 2013 yang berjudul: "Konstribusi Kemampuan Koneksi, Kemampuan Representasi Dan Disposisi Matematis Terhadap Prestasi Belajar Siswa SMA"

Hasil penelitiannya menyatakan bahwa kemampuan koneksi, kemampuan representasi dan disposisi matemais berkonstribusi secara signifikan terhadap prestasi belajar matematika siswa kelas XI IPA di Kabupaten Manggarai, baik secara langsung maupun tidak. Perbedaan penelitian oleh Kanisius Mandur, I Wayan Sandra, I Nengah Suparta dengan penelitian ini adalah:

a) Variabel yang diukur yaitu prestasi belajar sedangkan pada penelitian ini terhadap kemampuan representasi matematis.

a) Konstribusi kemampuan koneksi, representasi, disposisi matematis terhadap prestasi belajar sedangkan pada penelitian ini modifikasi model pembelajaran Gerlach dan Ely melalui integrasi nilai-nilai kelslaman untuk meningkatkan kemampuan representasi matematis peserta didik.

c. Penelitian oleh Nila Kurniawati yang berjudul: "Peningkatan Kemampuan Spasial Melalui Model Pembelajaran Gerlach Dan Ely Pada Pokok Bahasan Kubus Dan Balok".

Hasil penelitiannya menyatakan bahwa model pembelajaran Gerlach dan Ely dapat meningkatkan kemampuan spasial pada pokok bahasan kubus dan balok.

Perbedaan penelitian yang dilakukan oleh Nila Kurniawati dengan penelitian ini adalah: Variabel yang diukur yaitu kemampuan spasial, sedangkan pada penelitian ini yang diukur adalah kemampuan representasi matematis peserta didik. Persamaan dengan penelitian ini adalah model yang digunakan yaitu model pembelajaran Gerlach dan Ely.

Rumusan masalah dalam penelitian ini adalah :Apakah modifikasi model pembelajaran Gerlach dan Ely melalui integrasi nilai-nilai kelslaman dapat meningkatkan kemampuan representasi matematis peserta didik?

Berdasarkan rumusan masalah di atas, maka tujuan yang hendak dicapai dalam penelitian ini adalah untuk mengetahui apakah modifikasi model pembelajaran Gerlach dan Ely melalui integrasikan nilai-nilai kelslaman dapat meningkatkan kemampuan representasi matematis peserta didik.

Hipotesis dalam penelitian ini yaitu sebagai berikut:

a. $H_{0}: \mu_{1}=\mu_{2}$ (kemampuan representasi matematis peserta didik tidak meningkat setelah menggunakan modifikasi model pembelajaran Gerlach dan Ely yang diintegrasikan dengan nilai-nilai kelslaman dibanding kemampuan representasimatematis peserta didik sebelum menggunakan modifikasi model pembelajaran Gerlach dan Ely melalui integrasi nilai-nilai kelslaman).

b. $H_{1}: \mu_{1} \neq \mu_{2}$ (kemampuan representasi matematis peserta didik meningkat setelah menggunakan modifikasi model pembelajaran Gerlach dan Ely yang diintegrasikan dengan nilai-nilai kelslaman dibandingkan kemampuan representasi matematis peserta didik sebelum menggunakan modifikasi model pembelajaran Gerlach dan Ely melalui integrasi nilai-nilai kelslaman).

\section{METODE PENELITIAN}

Jenis penelitian ini adalah pre-experimental dengan desain One-group pretestposttest dimana membandingkan nilai tes awal (pretest) dan nilai tes akhir (posttest) untuk 
melihat kemampuan akhir peserta didik. Terdapat dua variabel dalam penelitian ini yaitu variabel bebas dan variabel terikat, yang menjadi variabel bebasnya adalah model pembelajaran Gerlach dan Ely yang diintegrasikan dengan nilai-nilai kelslaman dengan lambang (X) dan yang menjadi variabel terikatnya adalah kemampuan representasi matematis peserta didik dengan lambang (Y).Populasi yang digunakan dalam penelitian ini adalah peserta didik kelas VII MTs Unwanul Falah Punduh Pidada. Adapun sampel pada penelitian ini adalah peserta didik kelas VII A yang berjumalah 25 perserta didik.

Teknik pengumpulan data dalam penelitian ini menggunakan teknik dokumentasi dengan pengambilan gambar atau mendokumentasikan pada saat berlangsungnya penelitian, teknik observasi dengan pencatatan pola prilaku subyek (orang), obyek (benda), atau kejadian yang sistematis, tehnik wawancara digunakan oleh peneliti untuk mewawancarai guru mata pelajaran matematika, dan yang terakhir dengan menggunakan teknik tes, dalam penelitian ini tes yang digunakan berupa soal essay.

Instrumen yang digunakan dalam penelitian ini berbentuk tes. Tes kemampuan representasi yang digunakan dalam penelitian ini adalah tes uraian. Ketentuan dalam tes ini adalah setiap jawaban benar semua diberi skor 4 dan jawaban salah total diberi skor 0 atau dengan kata lain skor dalam interval (0-4) sehingga diperoleh skor mentah, kemudian skor tersebut ditransformasikan menjadi skala 0 sampai dengan 100.

Instrumen dalam penelitian ini adalah instrumen tes berupa tes bentuk uraian untuk mengukur kemampuan representasi matematis peserta didik. Sebelum dilakukan uji coba instrumen, maka soal yang akan di berikan harus di uji validitasnya, untuk melihat bahwa tes itu berdasarkan isinya valid, seseorang harus melihat bahwa instrumen yang akan diuji cobakan mewakili bahan yang akan diujikan, sesuai dengan standar kompetensi, kompetensi dasar, kurikulum, dan sesuain dengantujuan pembelajaran yang ingin dicapai. Dalam hal ini peneliti melibatkan pihak yang berkompeten untuk memeriksa validitasnya yakni pembimbing, dosen pendidikan matematika, dan guru pelajaran matematika.

Setelah melakukan uji coba instrumen sebelum instrumen diberikan kepada sampel peneliti melakukan uji validitas soal, uji tingkat kesukaran soal, uji daya pembeda soal dan uji reliabilitas soal untuk mengetahui baik atau tidaknya instrumen yang akan digunakan. Pengujian prasyarat analisis dilakukan dengan uji Liliefors untuk normalitas dan uji $F$ untuk homogenitas. Selanjutnya analisi data dalam penelitian ini menggunakan uji $\mathrm{N}$-Gain untuk mengetahui peningkatan kemampuan representasi matematis dan uji t-test berkorelasi untuk menguji hipotesis.

\section{HASIL PENELITIAN DAN PEMBAHASAN}

Berdasarkan hasil analisis data diperoleh data-data sebagai berikut:

Tabel 1. Deskripsi Data Skor Pretest dan Posttest Kemampuan Representasi Matematis

\begin{tabular}{lccccccc}
\hline \multirow{2}{*}{ Perlakuan } & \multirow{2}{*}{$\mathbf{X}_{\text {maks }}$} & $\mathbf{X}_{\min }$ & \multicolumn{2}{c}{ UkuranTendensiSentral } & \multicolumn{2}{c}{$\begin{array}{c}\text { UkuranVariansi } \\
\text { Kelompok }\end{array}$} \\
\cline { 3 - 8 } & & & $\overline{\mathbf{X}}$ & $\mathbf{M}_{\mathbf{0}}$ & $\mathbf{M}_{\mathbf{e}}$ & $\mathbf{R}$ & $\mathbf{S}$ \\
\hline Pretest & 65 & 30 & 44.400 & 45 & 45 & 35 & 10.928 \\
Posttest & 100 & 60 & 83.920 & 85 & 85 & 40 & 9.296 \\
\hline
\end{tabular}

Berdasarkan hasil tabel di atas, hasil tes sebelum proses pembelajaran (pretest) diperoleh nilai rata-rata $(\bar{X}) 44.400$, median $\left(M_{e}\right) 45$, modus (Mo) 45, rentang (R) 35, 
simpangan baku (S) 10.928, nilai tertinggi ( $\mathrm{X}_{\text {maks }}$ ) 65 dan nilai terendah ( $\left.\mathrm{M}_{\min }\right) 30$. Perhitungan data setelah proses pembelajaran (posttest) menggambarkan bahwa dari 25 peserta didik diperoleh nilai rata-rata $(\bar{X})$ 83.920, median $\left(M_{e}\right)$ 85, modus $\left(M_{0}\right)$ 85, rentang (R) 40, simpangan baku (S) 9.296, nilai tertinggi ( $\left.X_{\text {maks }}\right) 100$ dan nilai terendah $\left(M_{\min }\right) 60$.

Tabel 2. Rangkuman Hasil Prasyarat Normalitas Pretest dan Posttest

\begin{tabular}{lccccc}
\hline No & Perlakuan & N & Lhitung & Ltabel $_{\text {tal }}$ & KeputusanUji \\
\hline 1 & Pretest & 25 & 0.1581 & 0.1726 & Ho diterima (Normal) $_{2}$ \\
2 & Posttest & 25 & 0.1314 & 0.1726 & Hoditerima (Normal) \\
\hline
\end{tabular}

Berdasarkan keterangan tabel di atas, dari uji normalitas data amatan hasil tes kemampuan representasi matematis, tampak bahwa nilai L hitung pada perhitungan uji normalitas untuk setiap perlakuan kurang dari $\mathrm{L}_{\text {tabel }}\left(\mathrm{L}_{\text {hitung }}<\mathrm{L}_{\text {tabel }}\right)$. Hal ini berarti pada taraf signifikansi $\alpha=0.05, \mathrm{H}_{0}$ untuk setiap kelompok diterima. Dengan demikian data pada setiap perlakuan pretest dan posttest berasal dari data yang berdistribusi normal.

Hasil perhitungan uji homogenitas sebagai berikut:

a. Menentukan varians dari masing-masing kelompok data. Rumus varians

$$
\begin{aligned}
& \mathrm{S}_{1}{ }^{2}=\frac{\sum_{i=1}^{n}\left(x_{1}-\bar{x}\right)^{2}}{n-1}=\frac{2866}{24}=119.417 \\
& \mathrm{~S}_{2}{ }^{2}=\frac{\sum_{i=1}^{n}\left(x_{2}-\bar{x}\right)^{2}}{n-1}=\frac{2073.840}{24}=86.410
\end{aligned}
$$

b. Menentukan $F_{\text {hitung }}$ dengan rumus $F_{\text {hitung }}=\frac{\text { varianterbesar }}{\text { varianterkecil }}$

$$
\text { F hitung }=\frac{119.417}{86.410}=1.381
$$

c. Menentukan $F_{\text {tabel }}=F_{\frac{1}{2} \alpha}(25-1,25-1)=1.983$

d. Kesimpulan $F_{\text {hitung }}<F_{\text {tabel }}$ sehingga keputusan uji $\mathrm{H}_{0}$ diterima, artinya data berasal dari varians yang sama.

Tabel 3. Hasil Perhitungan Uji N-Gain Kemampuan Representasi Matematis

\begin{tabular}{ccccc}
\hline Diperoleh & Pretest & Posttest & N-gain & Kriteria \\
\hline$\Sigma$ & 1110 & 2098 & \multirow{2}{*}{0.710} & \multirow{2}{*}{ Tinggi } \\
$\bar{x}$ & 44.400 & 83.920 & & \\
\hline
\end{tabular}

Berdasarkan data yang diperolah pada tabel 12, maka hasil perhitungan menunjukkan adanya kriteria-kriteria sesuai nilai yang dicapai, N-gain 0.272 dengan perolehan nilai pretest 45 dan posttest 60 memperoleh kriteria rendah, adapun salah satu yang memperoleh kriteria tinggi dengan perolehan nilai pretest 65 dan posttest 100 dengan nilai $\mathrm{N}$-gain 1.000. Berdasarkan hasil yang diperoleh pada tabel 3 di atas, maka $\mathrm{N}$-gain secara keseluruhan adalah 0.710 . Perhitungan $\mathrm{N}$-gain ternormalisasi secara keseluruhan berdasarkan kriteria memperoleh kriteria tinggi.

Tabel 4. Hasil Perhitungan Uji T-Test Berkorelasi

\begin{tabular}{ccc}
\hline Diperoleh & Pretest & Posttest \\
\hline $\mathrm{N}$ & 25 & 25 \\
$s_{i}$ & 10.927 & 9.295 \\
\hline
\end{tabular}




\begin{tabular}{ccc}
\hline Diperoleh & Pretest & Posttest \\
\hline$s_{i}{ }^{2}$ & 119.417 & 86.410 \\
$\bar{x}$ & 44.400 & 83.920 \\
$R$ & 0.565 & \\
\hline$T_{\text {hitung }}$ & 20.722 & \\
\hline$T_{\text {tabel }}$ & 2.011 & \\
\hline
\end{tabular}

Karena $\left|t_{\text {hitung }}\right|>t_{\text {tabel }}$, maka $\mathrm{H}_{\mathrm{o}}$ ditolak artinya $\mathrm{H}_{1}$ diterima. Kesimpulan : Perhitungan menunjukkan $t_{\text {hitung }}>t_{\text {tabelyaitu }} 20.722>2.011$ sehingga dalam perhitungan $\mathrm{H}_{0}$ ditolak artinya $\mathrm{H}_{1}$ diterima yaitu :kemampuan representasi matematis peserta didik meningkat setelah menggunakan modifikasi model pembelajaran Gerlach dan Ely yang diintegrasikan dengan nilai-nilai kelslaman dibandingkan kemampuan representasi matematis peserta didik sebelum menggunakan modifikasi model pembelajaran Gerlach dan Ely melalui integrasi nilai-nilai kelslaman.

Modifikasi model pembelajaran Gerlach dan Ely melalui integrasi nilai-nilai kelslaman dapat menjadikan peserta didik lebih aktif, mudah memahami materi dan memotifasi peserta didik untuk ikut serta berpartisipasi dalam proses pembelajaran. Dalam Model pembelajaran Gerlach dan Ely terdapat sepuluh tahapan dalam proses pembelajaran yaitu merumuskan tujuan pembelajaran (specification of object), menentukan isi materi (specification of content), penilaian kemampuan awal siswa (assessment of entering behaviors), menentukan strategi (determination of strategy), pengelompokan belajar (organization of groups), menentukan pembagian waktu (allocation of times), menentukan ruang (allocation of space), memilih media instruksional yang sesuai (allocation of resources), mengevaluasi hasil belajar (evaluation of performance) dan menganalisis umpan balik (analisys of feedback). Modifikasi model pembelajaran Gerlach dan Ely dengan integrasi nilai-nilai kelslaman berada pada penentuan strategi dan memilih media instruksional yang akan digunakan dalam proses pembelajaran, strategi dan media yang digunakan merupakan keteladanan, ibrah dengan cerita, ceramah dan mau'zah (nasehat), tanya jawab, perumpamaan dan sindiran, demonstrasi, pembiasaan, pengalaman langsung, dan penugasan, serta penggunaan alat-alatdanmedia pembelajaran berupa wacana Islami, gambar-gambarataupotret-potret yang Islami dan praktik ibadah yang sesuai dengan kehidupan nyata.

Penelitian ini mempunyai dua variabel yang menjadi objek penelitian, yaitu variabel bebas (modifikasi model pembelajaran Gerlach dan Ely melalui integrasi nilai-nilai kelslaman) dan variabel terikat (kemampuan representasi matematis). Penelitian ini mengambil sampel kelas VII A yang berjumlah 25 peserta didik. Penulis meneliti sampel satu kelas yang diberikan dua perlakuan yaitu tes awal (pretest) dan tes akhir (posttest). Penelitian ini dilakukan lima kali pertemuan, satu kali pertemuan untuk tes awal kemampuan representasi matematis (pretest), tiga kali pertemuan untuk penerapan modifikasi model pembelajaran Gerlach dan Ely yang terintegrasi nilai-nilai kelslaman, satu kali pertemuan untuk tes akhir (posttest) kemampuan representasi matematis peserta didik.Sebelum soal tes kemampuan representasi matematis digunakan, terlebih dahulu divalidasi, kemudian diuji cobakan pada peserta didik kelas VIII A MTs Unwanul Falah Punduh Pidada Pesawaran. Tujuan uji coba ini adalah untuk mengetahui validitas butir soal dan tingkat reabilitas soal tes tersebut. 
Setelah memberikan pretest pada pertemuan pertama, maka pada pertemuan selanjutnya peserta didik diberikan pembelajaran dengan menggunakan modifikasi model pembelajaran Gerlach dan Ely melalui integrasi nilai-nilai kelslaman. Pembelajaran modifikasi model Gerlach dan Ely melalui integrasi nilai-nilai kelslaman terlebih dahulu guru menyampaikan tujuan pembelajaran atau target yang ingin dicapai dalam kegiatan pembelajaran, guru menentukan pokok bahasan yang lebih spesifik agar apa yang akan diberikan lebih jelas dan mudah dipahami siswa serta sesuai dengan tujuan yang ingin dicapai, guru melaksanakan penilaian kemampuan awal (pretest) pada materi yang akan diberikan agar dapat memberikan dosis pelajaran yang tepat. Dalam Proses pembelajaran peserta didik juga dibagi menjadi kelompok-kelompok kecil dimana satu kelompok maksimal terdiri dari 5 orang peserta didik. Setiap kelompok diberikan suatu masalah yang harus dipecahkan, peserta didik diberi kesempatan untuk menuangkan ide-ide kreatifnya dalam menjawab masalah dengan caranya sendiri, jadi peserta didik diberi kebebasan untuk menyampaikan pemikirannya dalam menyelesaikan masalah yang diberikan dan peserta didik harus lebih aktif dari pada guru. Saat diskusi guru berlaku sebagai pembimbing, fasilitator dan motivator yang hanya mengarahkan peserta didik. Pada tahap elaborasi guru memilih peserta didik secara acak dari masing-masing kelompok yang akan mempresentasikan kerja kelompoknya sementara peserta didik yang lain memperhatikan, menanggapi ataupun memberikan pertanyaan.

Pada pertemuan pertama, materi pembelajaran adalah mengidentifikasi jenis-jenis segitiga berdasarkan sisi dan besar sudutnya. Media yang digunakan adalah bentuk-bentuk segitiga dari karton serta pengintegrasian nilai-nilai kelslaman dengan menghubungkan jenis-jenis segitiga berdasarkan besar sudutnya dengan memperagakan gerakan shalat dan menentukan sudut apa yang terbentuk ketika gerakan i'tidal, ruku' dan sujud. Kendala yang dihadapi dalam proses pembelajaran pada pertemuan pertama adalah sulitnya peneliti membuat peserta didik mau maju kedepan untuk memperagakan gerakan shalat karena pengintegrasian nilai-nilai Islam dalam pembelajaran matematika baru pertama kali dilaksanakan di MTs Unwanul Falah sehingga membuat peneliti harus mengulangi instruksi beberapa kali serta menunjuk secara langsung untuk perwakilan setiap kelompok maju kedepan. Solusi agar pada pertemuan kedua tidak ada kendala yang sama sebelum mengakhiri pertemuan pertama peneliti menjelaskan secara rinci bahwa pembelajaran yang peneliti berikan diintegrasikan dengan nilai-nilai kelslaman dan peserta didik diminta untuk berperan aktif dalam proses pembelajaran.

Selanjutnya pada pertemuan kedua dengan materi mengidentifikasi masalah yang berkaitan dengan keliling dan luas segitiga serta segiempat. Media yang digunakan yaitu benda-benda nyata didalam kelas seperti meja, papan tulis dan gambar-gambar bangun segiempat yang sudah peneliti siapkan. Kendala pada pertemuan kedua hanya terletak pada waktu, karena setiap kelompok dalam presentasi menjelaskan secara rinci dan terlalu banyak pertanyaan dari kelompok lain sehingga tidak semua kelompok dapat maju ke depan untuk mempresentasikan hasil kerja kelompoknya. Solusi yang peneliti gunakan untuk pertemuan selanjutnya, peneliti akan membatasi atau memberikan waktu yang sama pada setiap kelompok dalam presentasi dan hanya tiga pertanyaan yang diajukan dari kelompok lain.

Pada pertemuan ketiga dengan materi penyelesaian masalah dengan menggunakan rumus segitiga dan segiempat yang berkaitan dengan menentukan keliling dan luas, serta 
memecahkan masalah tersebut. Pada pertemuan ketiga ini, pembelajaran berjalan dengan baik dan tidak ada kendala ketika proses pembelajaran berlangsung. Peserta didik mempresentasikan jawaban dari soal yang telah diselesaikan secara berkelompok. Peserta didik perwakilan dari setiap kelompoknya secara bergantian menjelaskan dengan cara masing-masing untuk mengetahui cara penyelesaian permasalahan soal tersebut.

Secara keseluruhan pembelajaran dengan modifikasi model pembelajaran Gerlach dan Ely melalui integrasi nilai-nilai kelslaman berjalan dengan baik. Selama proses belajar mengajar berlangsung terlihat adanya perubahan yang diperoleh peserta didik yakni meningkatnya kemampuan representasi matematis peserta didik. dapat dilihat pada lampiran-lampiran tabel bahwa adanya peningkatan kemampuan representasi matematis peserta didik setelah menggunakan modifikasi model pembelajaran Gerlach dan Ely yang terintegrasi nilai-nilai kelslaman. Adapun terlihat bahwa rata-rata kemampuan representasi matematis peserta didik lebih dari rata-rata kemampuan representasi matematis peserta didik sebelum menggunakan modifikasi model pembelajaran Gerlach dan Ely yang terintegrasi nilai-nilai kelslaman, sehingga diperolah kesimpulan bahwa modifikasi model pembelajaran Gerlach dan Ely yang terintegrasi nilai-nilai kelslaman dapat meningkatkan kemampuan representasi matematis karena dapat memudahkan proses pembelajaran peserta didik dalam memahami materi segitiga dan segiempat.

Data berupa nilai kemampuan representasi matematis peserta didik yang diperoleh dari hasil pretest dan posttest tersebut telah dilakukan perhitungan uji analisis data Uji-t berkorelasi yakni berupa uji normalitas dan uji homogenitas. Berdasarkan perhitungan uji normalitas diperoleh pretest dan posttest berasal dari populasi yang berdistribusi normal. Uji prasyarat dilanjutkan dengan uji homogenitas untuk mengetahui apakah data penelitian mempunyai variansi yang sama atau tidak. Berdasarkan hasil perhitungan yang dilakukan peneliti menunjukkan bahwa data pretest dan posttest berasal dari varians yang sama atau homogen.

Uji prasyarat telah terpenuhi sehingga dilanjutkan pada uji hipotesis dengan Uji gain ternormalisasi danUji-t berkorelasi. Berdasarkan perhitungan $\mathrm{N}$-gainsecara rata-rata dengan tujuan untuk melihat apakah terdapat peningkatan kemampuan representasi matematis peserta didik, dari hasil analisis yang telah dilakukan bahwa dengan menggunakan modifikasi model pembelajaran Gerlach dan Ely melalui integrasi nilai-nilai kelslaman peserta didik memiliki peningkatan kemampuan representasi matematis. Pada uji $N$-gain terlihat kriteria yang diperoleh secara keseluruhan adalah kriteria tinggi, dimana hasil posttest lebih tinggi dibandingkan hasil pretest. Selanjutnya, berdasarkan analisis datauji t-test berkorelasi diperoleh bahwa terdapat peningkatan kemampuan representasi matematis peserta didik setelah diberikan pembelajaran menggunakanmodifikasi model pembelajaran Gerlach dan Ely melalui integrasi nilai-nilai kelslaman.

Secara keseluruhan kemampuan representasi matematis peserta didik setelah diberikan pembelajaran dengan modifikasi model pembelajaran Gerlach dan Ely melalui integrasi nilai-nilai kelslaman memiliki peningkatan yang signifikan dibandingkan dengan kemampuan representasi matematis peserta didik sebelum diberikan pembelajaran dengan modifikasi model pembelajaran Gerlach dan Ely melalui integrasi nilai-nilai kelslaman. 


\section{SIMPULAN DAN SARAN}

Berdasarkan hasil penelitian, analisis, dan pengolahan data maka dapat dikesimpulkan bahwa: Modifikasi model pembelajaran Gerlach dan Ely melalui integrasi nilai-nilai kelslaman dapat meningkatkan kemampuan representasi matematis peserta didik. Oleh karena itu, disarankan bagi peneliti lain dapat menggunakan model ini sehingga dapat meningkatkan pembelajaran.

\section{DAFTAR PUSTAKA}

Armiah. (2014). Internalisasi Nilai-Nilai Keagamaan Lewat Media. Jurnal IImu Dakwah, IAIN Antasari.

Effendi, L. A. (2014). Pembelajaran Matematika dengan Metode Penemuan Terbimbing untuk Meningkatkan Kemampuan Representasi dan Pemecahan Masalah Matematis Siswa SMP. Jurnal Pendidikan Pasca Sarjana UPI, 11-18.

Gagatsis, A. d. (2004). Ability to Translate from One Representation of the Concept of Function to Another and Mathematical Problem Solving. International Journal, Vol. 24 No 5., 2-12.

Isjoni. (2014). Cooperative Learning. Bandung: Alfabeta.

Purwanto, M. N. (2007). Evaluasi Pembelajaran. Bandung: CV Wacana Prima.

Rusman. (2013). Model-model Pembelajaran. Jakarta: Rajawali Pers.

Sudijono, A. (2013). Pengantar Evaluasi Pendidikan. Jakarta: PT. Raja Grafindo Persada.

Sugiyono. (2012). Metode penelitian kuantitatif, kualitatif dan $R$ \& D. Bandung: Alfabeta.

Suherman. (2015). Kreativitas Siswa Dalam Memecahkan Masalah Matematika Materi Pola Bilangan dengan Pendekatan Matematika Realistik (PMR). Al-Jabar : Jurnal Pendidikan Matematika, 81-90.

Widyastuti, R. (2015). Proses Berpikir Siswa dalam Menyelesaikan Masalah Matematika berdasarkan Teori Polya ditinjau dari Adversity Quotient Tipe Climber. Al-Jabar: Jurnal Pendidikan Matematika, 193-203. 